\title{
SPINEL LHERZOLITE NODULES IN BASANITE LAVAS FROM ASUNCION, PARAGUAY
}

\author{
J. C. STORMER, Jr.*, C. B. GOMES**, and \\ J. R. F, TORQUATO***
}

\begin{abstract}
Spinel therzolites were found in basanite flows in the vicinity of Asuncion, Paraguay. Electron microprobe analyses show that the olivine, clinopyroxene and orthopyroxene compositions are very similar to other occurrences of lherzolite. The spinel, however, is rich in $\mathrm{Fe}^{+3}, \mathrm{Cr}$ and $\mathrm{Mg}$ with respect to other lherzolites. Olivine and pyroxene in the basanite show compositional trends consistent with lowering silica activity as a function of pressure. Plagioclase showing extensive zoning and nepheline with excess silica are found in the groundmass. Several pressure-temperature indicators suggest that the spinel lherzolites equilibrated near $1100^{\circ} \mathrm{C}$ at a depth of about $45 \mathrm{~km}$.

Initial $\mathrm{Sr}_{87} / \mathrm{Sr}_{86}$ ratios for both the nodule and basanite are similar and are consistent with mantle values. Potassium-argon age determination indicates an Eocene age. This age suggests that volcanism in the Asuncion area was associated with the development of the Ypacaray Graben.
\end{abstract}

RESUMO Nódulos de espinélio lherzolitos foram encontrados em lavas basaníticas nas proximidades de Assunção, Paraguai.

Análises por microssonda indicam que a composição das olivinas, ortopiroxênios e clinopiroxênios é similar àquela encontrada em ocorrências congêneres. Os espinélios, no entanto, apresentam-se mais ricos em $\mathrm{Fe}^{3+}, \mathrm{Cr}$ e $\mathrm{Mg}$ relativamente a outros lherzolitos. As olivinas e os piroxênios dos basanitos exibem variaçð̃es na composição de acordo com o abaixamento da atividade da ślica em função da pressão. Plagioclásios mostrando extenso zoneamento e nefelina com silica em excesso acham-se presentes na massa fundamental. Diversos indicadores de pressão e temperatura sugerem que os espinélio therzolitos estiveram em equilíbrio a cerca de $1100^{\circ} \mathrm{C}$ e a uma profundidade aproximada de $45 \mathrm{~km}$.

As razðes iniciais $\mathrm{Sr}_{87} / \mathrm{Sr}_{86}$ são similares para nódulos e basanito, e consistentes com os valores do manto. A idade Eocênica obtida pelo método $\mathrm{K} /$ Ar sugere que o vulcanismo na área de Assunção esteve associado ao desenvolvimento do Graben de Ypacaray.

INTRODUCTION During a visit to Paraguay in June, 1973, we noticed a basaltic rock containing ultramafic nodules being used for road building in Asunción. One source of this material was located on a small hill, Cerrito Cantera, in the northwestern part of the city. There, in a quarry, the nodules were found to occur in a flow several meters thick which was apparently overlain by a thick chaotic deposit of altered cinders and scoria. There may well be other sources of this material in the area, since the geology of the region is not known in detail. Unfortunately, the nature of our trip precluded any real investigation of the geological field relations. Asunción is located on the western edge of the Paraná Basin and these rocks apparently lie on top of the mesozoic Misiones sandstone found in the vicinity. The Ypacaray Graben (Fig. 1) of Eocene age is the major structural feature in the area (Fúlfaro and Landim, 1971).

Although the occurrence of spinel lherzolite nodules is a relatively uncommon geological phenomenon, they are characteristically found in nephelinites and basanites of both oceanic and continental provinces. For many years these nodules have been considered to be fragments of mantle material torn loose and carried to the surface by volcanic processes. Carmichael et al. (1974) have presented a review of the data available on such nodules.

*University of Georgia, Department of Geology, Athens, Georgia 30602, EUA

**Universidade de São Paulo, Instituto de Geociências, Caixa Postal, 20899, Såo Paulo, Brasil

***Universidade Federal da Bahia, Instituto de Geociências, Salvador, Bahia 


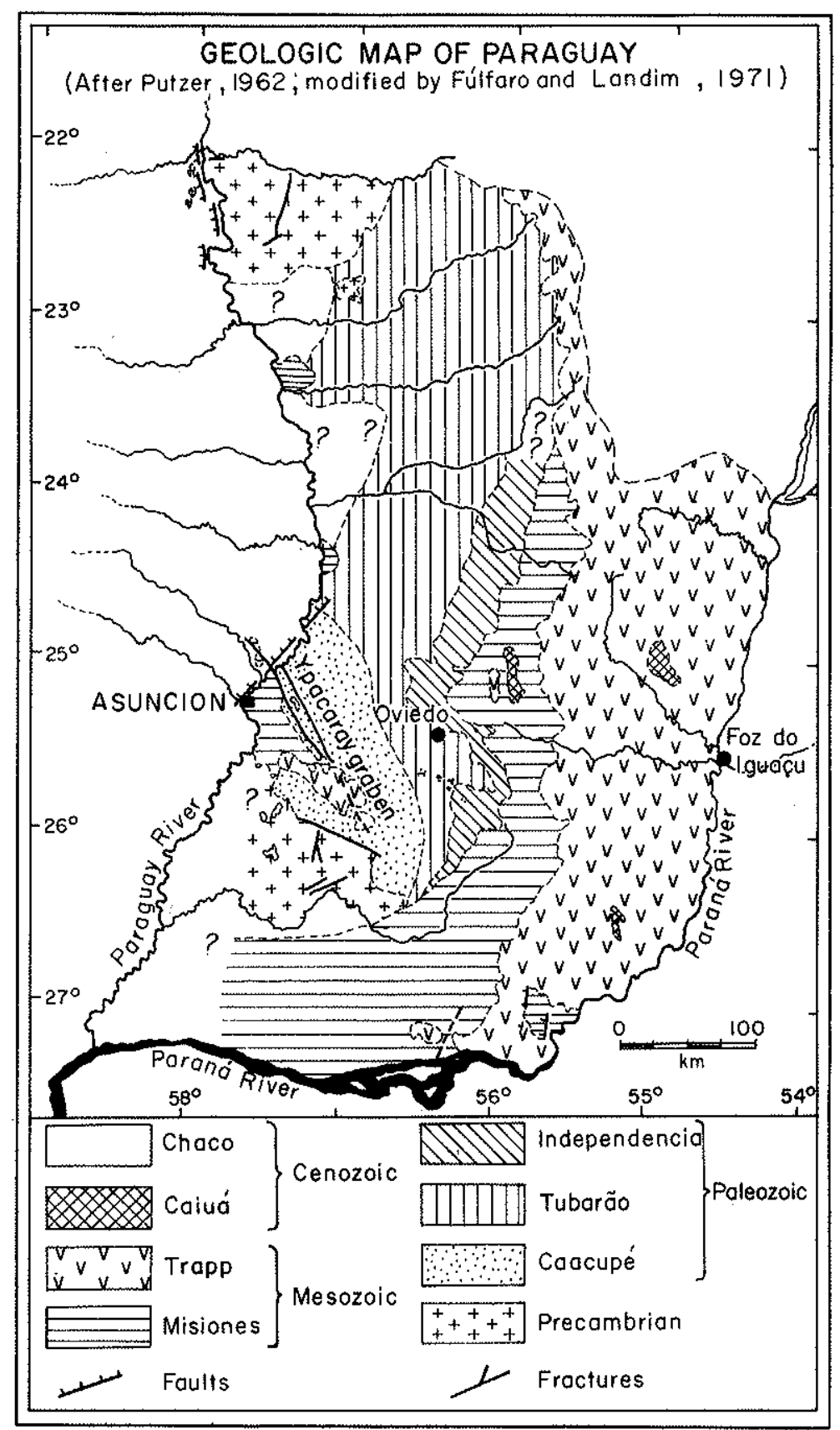

Figure 1-Geologic map of Paraguay

Chemical, isotopic and textural criteria generally rule out a cumulate origin from the enclosing magma, and the mineral assemblages in them indicate that they equilibrate at temperatures and pressures appropriate to the upper mantle. However, the relationship of lherzolite nodules to the host rocks and to the composition of the upper mantle still present unanswered questions. 
The discovery of the nodules from Asunción was reported by us in 1973 at the II Latinamerican Geological Congress in Caracas, Venezuela (Stormer et al., 1973). In this paper we are presenting the detailed results of the chemical and mineralogical analyses.

PETROGRAPHY Host Rock The host rock is a dark very fine grained porphyritic basanite with phenocrysts of olivine and subordinate clinopyroxene of variable size ranging up to $2 \mathrm{~mm}$. The pyroxene was strongly zoned, often with an irregular core suggesting that the phenocryst might have been a fragment of a pre-existing mineral grain which had subsequently been overgrown. In general the olivine in the host rock seemed to be anhedral and unzoned without evidence of deformation, although in a few samples there was faint evidence of magmatic corrosion.

The groundmass has a hypidiomorphic granular texture consisting predominantly of pyroxene with minor olivine and very fine grained plagioclase laths. There is interstitial nepheline and alkali feldspar (of anorthoclase composition) which is quite variable in amount from place to place in the rock. Although not identified optically, a very few microprobe data points high in sodium suggest that a small amount of sodalite or nosean is also present. Magnetite and apatite are found as accessories.

Nodules The nodules studied are, with one exception, spinel lherzolite. They are irregular in shape tending to be somewhat rounded, and range in size from a few millimeters to several centimeters. Both mineralogically and texturally they are essentially identical to the common type from other localities ( $c f$. White, 1966; Bacon and Carmichael, 1973). White's (1966) description of lherzolite nodules, one of the most detailed, could equally well be applied to these. The texture is xenomorphic granular, grain size variable between 0.2 and $5 \mathrm{~mm}$, composed primarily of olivine with subordinate amounts of orthopyroxene and clinopyroxene, and small amounts of spinel: The olivine is anhedral equigranular showing well developed deformation lamellae and ondulatory extinction. The orthopyroxene is anhedral and equigranular with abundant exsolution lamellae. Although averaging somewhat larger in size than other minerals, the orthopyroxene grains were also variable in size and not noticeably "porphyroblastic". There is conspicuous alteration of orthopyroxene to an aggregate of fine grained olivine in a cryptocrystalline matrix where it is in contact with the host rock (exactly as described and illustrated in White's 1966 paper). Clinopyroxene is also roughly equigranular sometimes showing the marginal porosity and alteration described by White (1966). The spinel is of a light greenish brown color in anhedral irregularly lobate masses, apparently interstitial. At the margins it is often altered to fine grained mixture of opaque oxides and unrecognizable (feldspathic?') material. Some crystals are surrounded by an aggregate of very small olivine grains, a texture very much like the alteration of orthopyroxene noted above. No other phases (such as sulfides) were noted as constituents of the nodules. Glassy and "feldspathic" material occurred in cracks, probably invading from the host magma.

A single inclusion of quartz-feldspathic material was found. Because of its small size $(2 \times 5 \mathrm{~mm})$ and somewhat altered condition, the description is inexact. It is fine grained and equigranular consisting of anhedral sanadine and quartz with prismatic grains of sodium rich clinopyroxene. There is no apparent alignment of these grains or foliation. This nodule does not have a resemblance to any common plutonic or metamorphic rock type.

Chemical Analyses Minerals The minerals of the lherzolite nodules and in the host rock were analysed using electron microprobe techniques. Most of the analyses were made on the 
Applied Research Laboratory EMX microprobe in the "Instituto de Geociências", University of São Paulo. The three crystal spectrometers were tuned to the designed $K_{\alpha}$ radiation with crystal (RAP, ADP, LiF) and detector combination to give the maximum count rate at $15 \mathrm{keV}$ excitation and sample currents of about $0.05 \mu \mathrm{A}$. Counts were collected using constant integrated beam current for times varying between 15-20 s on 20 or more analysis points. Analyses for $\mathrm{Na}, \mathrm{K}, \mathrm{Ca}$ (feldspars only), $\mathrm{Mn}, \mathrm{Cr}$, and $\mathrm{Ni}$ and replicate analyses for Fe were made on the Materials Analysis Co. 400-S microprobe at the University of Georgia under the same conditions except for the use of regulated beam current and constant $20 \mathrm{~s}$ counting intervals. The standards used were well analysed natural silicates and synthetic oxides selected to minimize matrix correction effects. Dead time was not significant and standard correction procedures were applied for background, drift, and matrix effects using the appropriate oxide correction factors of Albee and Ray (1970). In addition all minerals were checked for unanalysed constituents by accumulating a complete X-ray spectrum from 0.7 to $10.2 \mathrm{keV}$ using a Canberra 8100 energy dispersive analysis system (154 eV resolution at $5.9 \mathrm{keV}$ ) fitted to the MAC 400 probe. Measurements on standard minerals indicate a minimum detection limit under the conditions used of not more than $0.5 \%$ for any element. These results confirmed the analysis made with the crystal spectrometers.

The analysis of groundmass feldspars and nepheline are presented in Fig. 2A. The plotted points for feldspar are for those $\mathrm{Na}, \mathrm{Ca}$, and $\mathrm{K}$ analyses which totaled between 98.0 and 101.0 after converting to the stoichiometric end member compositions $\mathrm{NaAlSi}_{3} \mathrm{O}_{8}$, $\mathrm{CaAl}_{2} \mathrm{Si}_{2} \mathrm{O}_{8}$, and $\mathrm{KAlSi}_{3} \mathrm{O}_{8}$. There is extensive normal zoning from labradorite in the cores of the laths at least to potash rich oligoclase in the very rims and interstitial material. The extent of this zonation is difficult to establish due to the very small size of the grains. The compositions of these feldspars are quite comparable with groundmass feldspars from similar basanite and alkali basalt lavas (Stormer, 1972; Bacon and Carmichael, 1973). Analysis of feldspars from the quartz-feldspathic inclusion are also plotted in the same diagram although they are probably totally unrelated to the basanite. These are obviously high temperature sanadine, $\mathrm{Ab}_{40-50}$, also very low in anorthite (less than $0.5 \%$ ).

Those nepheline analysis which appeared to represent good values were recalculated to stoichiometric end members $\mathrm{NaAlSiO}_{4}, \mathrm{KAlSiO}_{4}$ and $\mathrm{CaAl}_{2} \mathrm{Si}_{2} \mathrm{O}_{4}$. Excess $\mathrm{SiO}_{2}$ was then determined by difference. Calcium contents were moderately high, yielding an average of about $2.2 \% \mathrm{CaAl}_{2} \mathrm{Si}_{2} \mathrm{O}_{4}$ molecule. The results of the analysis in terms of $\mathrm{NaAlSiO}_{4}$, $\mathrm{KAlSiO}_{4}$ and excess silica are presented in Fig. 2B. There is considerable scatter in the plotted points but no consistent zoning trend was observable. Part of the scatter may be due to the determination of excess $\mathrm{SiO}_{2}$ by difference. However, the scatter is not distributed along a line of constant $\mathrm{Na}-\mathrm{K}$ ratio as might then be expected. The direction and extent of this scatter is virtually identical to the variations in nephelines studied by Brown (1970). Brown hypothesized that such variation could be due to incipient unmixing of once homogeneous nepheline to a very fine mixture of alkali feldspar and a more silica-poor nepheline. It would be impossible to test the hypothesis in any way since our material is interstitial in a fine grained groundmass and very difficult to analyse at all. The position of the normative composition of the rock in this system, lying on the extension of the trend, does lend some support to such a hypothesis.

Analysis of olivines, pyroxenes and spinel from both the host rock and the lherzolite nodules are presented in Table I. As other investigators have found, the minerals in lherzolite nodules are virtually identical throughout the world ( $c f$. White, 1966; Bacon and Carmichael 1973, among many others). The nodules from Asunción are no exception. Table I also presents the cation proportions (formula ratios) for each element relative to 
Figure 2 - Composition of Feldspars and Nepheline. A) Composition of feldspars recalculated to end member molecules An $\left(\mathrm{CaAl}_{2} \mathrm{Si}_{2} \mathrm{O}_{8}\right)$, Ab $\left(\mathrm{NaAlSi}_{3} \mathrm{O}_{8}\right)$, and Or $\left(\mathrm{KAlSi}_{3} \mathrm{O}_{8}\right)$. B) Composition of nepheline projected onto the system $\mathrm{Ne}-\mathrm{K}_{\mathrm{p}}-\mathrm{Q}_{\mathrm{z}}$ $\left(\mathrm{Na}-\mathrm{AlSiO}_{4}-\mathrm{KAlSiO}_{4}-\mathrm{SiO}_{2}\right)$

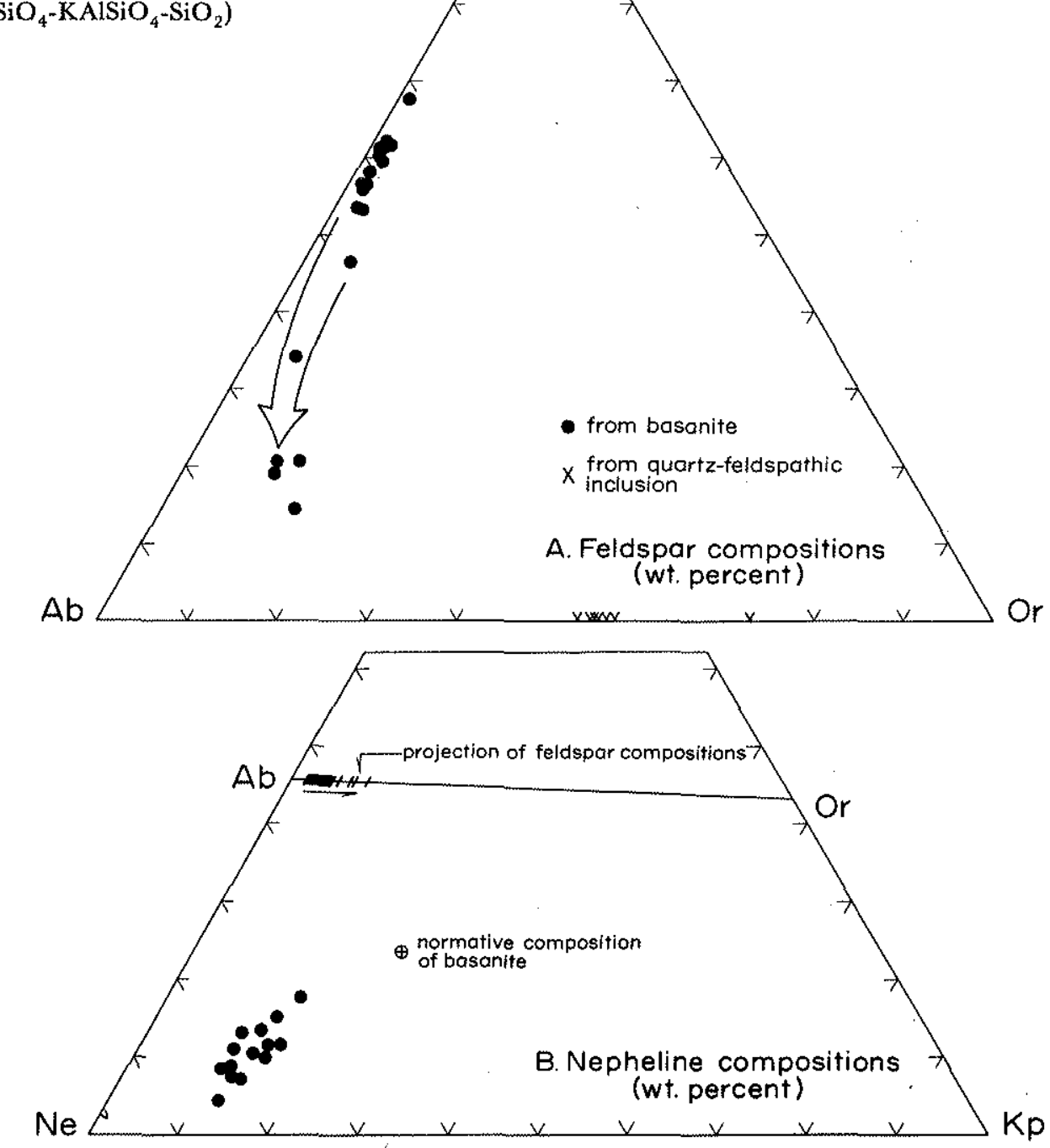

the customary number of oxygens in the mineral formula. All analysis give reasonable formulae as well as oxide totals. Calculated mineral "molecules" as also presented in Table I, have no basis in physical reality and may in fact be misleading as representations of chemical components in mineral equilibria. These calculated molecules are, however, useful to illustrate differences and to facilitate comparisons between mineral analyses.

The olivines from the lherzolites are near $\mathrm{Fo}_{90}$ with very low $\mathrm{Ca}$ contents. The olivine phenocrysts in the host rock are much richer in calcium as well as iron. Neither olivine is significantly zoned but the trend of strongly increased $\mathrm{Ca}$ with increasing $\mathrm{Fe}$ between nodule and host exactly parallels trends for basanite and nephelinite olivine zoning studied 
Table I - Olivine, pyroxene and spinel analyses

\begin{tabular}{|c|c|c|c|c|c|c|c|c|}
\hline & $\begin{array}{l}\text { 1. Olivine } \\
\text {-nodule }\end{array}$ & $\begin{array}{l}\text { 2. Olivine } \\
\text { pheno. }\end{array}$ & $\begin{array}{l}\text { 3. Clinopx. } \\
\text {-nodule }\end{array}$ & $\begin{array}{l}\text { 4. Cpx. pheno. } \\
\text { core }\end{array}$ & $\begin{array}{l}\text { 5. Cpx. pheno. } \\
\text { rim }\end{array}$ & $\begin{array}{l}\text { 6. Cpx. } \\
\text { groundmass }\end{array}$ & $\begin{array}{l}\text { 7. Orthopx. } \\
\text {-nodule }\end{array}$ & $\begin{array}{l}\text { 8. Spinel } \\
\text {-nodule }\end{array}$ \\
\hline $\mathrm{SiO}_{2}$ & 40.3 & 37.4 & 54.5 & 54.3 & 46.5 & 46.2 & 54.5 & *** \\
\hline $\mathrm{TiO}_{2}$ & $* *$ & $* *$ & 0.1 & 0.1 & 2.9 & 3,0 & $\operatorname{tr}$ & $* *$ \\
\hline $\mathrm{Al}_{2} \mathrm{O}_{3}$ & *** & ** & 4.6 & 2.8 & 8.1 & 8.4 & 2.8 & 46.3 \\
\hline $\mathrm{Cr}_{2} \mathrm{O}_{3}$ & $* *$ & *** & 0.6 & 0.6 & 0.1 & nd & 0.2 & 15.2 \\
\hline $\mathrm{FeO}^{*}$ & 10.0 & 21.3 & 2.6 & 2.5 & 7.5 & 7.6 & 6.5 & $12.4\left\{12.5 \mathrm{Fe}_{2} \mathrm{O}_{3}^{* * *}\right.$ \\
\hline $\mathrm{MnO}$ & 0.1 & 0.4 & 0.1 & 0.1 & 0.2 & nd & nd & $0.1(1.1 \mathrm{FeU}$ \\
\hline $\mathrm{MgO}$ & 48.7 & 46.0 & 15.4 & 16.8 & 11.3 & 11.0 & 34.0 & 24.6 \\
\hline $\mathrm{CaO}$ & 0.08 & 0.6 & 21.6 & 22,5 & 23.5 & 22.2 & 0.4 & ** \\
\hline $\mathrm{Na}_{2} \mathrm{O}$ & ** & ** & 1.5 & 1.1 & 0.9 & nd & 0.1 & ** \\
\hline $\mathrm{NiO}$ & 0.4 & 0.2 & 1.0 & 0.1 & 0.1 & nd & 0.1 & 0.4 \\
\hline Total & 99.6 & 99.9 & 101.1 & 100.9 & 101.1 & $(98.4)$ & 98.6 & 99.0 \\
\hline
\end{tabular}

Cation proportions relative to number of formula oxygens

\begin{tabular}{|c|c|c|c|c|c|c|c|c|c|c|c|c|c|c|}
\hline 0 & & & 4 & 6 & & 6 & 6 & & 6 & 6 & & 4 & & \\
\hline $\mathrm{Si}$ & 95 & & .976 & 1.948 & & $1.953)$ & $1.731)$ & & 1.751 & 1.914 & & - & & \\
\hline $\mathrm{Ti}$ & - & & - & .003 & & .003 & .081 & & .085 & $-m$ & & - & & \\
\hline $\mathrm{Al}$ & - & & - & .194 & & .119 & .355 & & .375 & .116 & & 1.482 & & \\
\hline $\mathrm{Cr}$ & $-\sqrt{-1}$ & & - . & .017 & & .017 & .003 & & - & .006 & & .326 & $256 \mathrm{Co}+3$ & \\
\hline $\mathrm{Fe}$ & $07)$ & & $.464)$ & .078 & & .075 & .233 & & .241 & .191 & & .282 & $.256 \mathrm{Fe}^{+3}$ & \\
\hline $\mathrm{Mn}$ & 02 & & .009 & .003 & 3.99 & .003 & .006 & 4.04 & $\ldots$ & س- & 4.03 & .002 & $\left..026 \mathrm{Fe}^{+2}\right\}_{3}$ & 3.09 \\
\hline $\mathrm{Mg}$ & 913 & & $1.554\}_{205}$ & .820 & & .900 & .627 & & .621 & 1.778 & & .995 & & \\
\hline $\mathrm{Ca}$ & $023^{2}$ & & $.017\}^{2.05}$ & .827 & & .867 & .937 & & .901 & .015 & & - & & \\
\hline $\mathrm{Na}$ & - & & - & $.104\}$ & & .077 & .065 & & - & .007 & & - & & \\
\hline $\mathrm{Ni}$ & 108) & & $.004)$ & .003 & & .003 & .003 & & - & .003 & & .009 & & \\
\hline \multicolumn{15}{|c|}{ Mineral "molecules" - mole percent } \\
\hline \multirow{9}{*}{$\begin{array}{l}\mathrm{Fe}_{2} \mathrm{SiO}_{4} \\
\mathrm{Mg}_{2} \mathrm{SiO} \\
\mathrm{Ca}_{2} \mathrm{SiO}_{4} \\
\mathrm{Mn}_{2} \mathrm{SiO} \\
\mathrm{Ni}_{2} \mathrm{SiO}_{4}\end{array}$} & 89.1 & 75.9 & $\mathrm{CaTiAl}_{2} \mathrm{O}_{6}$ & 0.3 & & 0.3 & 8.0 & & - & & - & \multirow{9}{*}{\multicolumn{3}{|c|}{$\begin{array}{ll}\mathrm{MgCr}_{2} \mathrm{O}_{4} & 15.8 \\
\mathrm{MnAl}_{2} \mathrm{O}_{4} & 0.2 \\
\mathrm{NiAl}_{2} \mathrm{O}_{4} & 0.9 \\
\mathrm{MgAl}_{2} \mathrm{O}_{4} & 70.7 \\
\mathrm{MgFe}_{2} \mathrm{O}_{4} & 9.9 \\
\mathrm{FeFe}_{2} \mathrm{O}_{4} & 2.5 \\
\mathrm{Mg}_{\mathrm{Fe}}+2 & \mathrm{Mg} \\
\mathrm{Fe}^{+3} / \mathrm{Fe}^{+3}+\mathrm{Al}+\mathrm{Cr}=0.97 \\
\mathrm{Cr} / \mathrm{Fe}^{+3}+\mathrm{Al}+\mathrm{Cr}=0.12 \\
=0.16\end{array}$}} \\
\hline & 10.2 & 22.7 & $\mathrm{CaCrAlSiO}_{6}$ & 1.7 & & 1.7 & 0.3 & & سـ & & - & & & \\
\hline & 0.1 & 0.8 & $\mathrm{CaAl}_{2} \mathrm{SiO}_{6}$ & 2.9 & & 2.4 & 8.5 & & - & & $一$ & & & \\
\hline & & 0.4 & $\mathrm{NaAlSi}_{2} \mathrm{O}_{6}$ & 10.4 & & 4.7 & 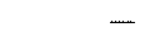 & & - & & - & & & \\
\hline & 0.4 & 0.2 & $\mathrm{NaFeSi}{ }_{2} \mathrm{O}_{6}$ & - & & 3.1 & 6.3 & & - & & 0.7 & & & \\
\hline & & & $\mathrm{CaSiO}_{3}$ & 39.0 & & 40.8 & 37.7 & & - & & 0.7 & & & \\
\hline & & & $\mathrm{MgSiO}_{3}$ & 41.1 & & 44.7 & 30.9 & & - & & 88.1 & & & \\
\hline & & & $\mathrm{FeSiO}_{3}$ & 3.9 & & 2.1 & 8.3 & & + & & 9.1 & & & \\
\hline & & & & & & & & & & $\mathrm{Al}_{2} \mathrm{O}_{3}$ & 2.7 & & & \\
\hline
\end{tabular}

*All iron is reported as $\mathrm{FeO}$

**Below limit of detection $\left(0.02 \%\right.$ for $\mathrm{TiO}_{2}, \mathrm{CaO}$ and $\mathrm{Cr}_{2} \mathrm{O}_{3}-0.05 \%$ for $\mathrm{SiO}_{2}, \mathrm{Al}_{2} \mathrm{O}_{3}$ and $\left.\mathrm{Na}_{2} \mathrm{O}\right)$ nd Not analysed

***Calculated by assignment of cations to spinel "molecules" as described in text

by Stormer (1973). These trends were shown to relate to changes in silica activity in the magma probably due to large drops in pressure as the magma rose from depth.

The analysis of clinopyroxene from the nodule and host rock show some interésting relationships. The phenocryst rims show the reduced silica content and increased $\mathrm{TiO}_{2}$ and $\mathrm{Al}_{2} \mathrm{O}_{3}$ characteristic of pyroxenes crystallizing at low pressure from alkaline magmas due to the low silica activities (Verhoogen, 1962; Le Bas, 1962; Stormer, 1972). The analysis of clinopyroxene from the nodule at first seems very similar to the analysis of the phenocryst cores, which had the appearance of fragments of pre-existing grains. This suggests that these cores might, in fact, be pieces derived from the nodules. However, the calculation of the mineral molecules brings out some fairly significant differences. The $\mathrm{NaAlSi}_{2} \mathrm{O}_{6}$ "molecule", in particular, is very high in the nodule, drops by half in the cores of the phenocrysts, and is not present in the rim, while the $\mathrm{NaFe}^{+3} \mathrm{Si}_{2} \mathrm{O}_{6}$ component shows the opposite relationship. The phenocryst cores do fall within the range of analysis of other lherzolite clinopyroxenes, but they do not represent material identical to the clinopyroxenes 
in our nodules. They have either been significantly modified by reaction with magma, derived from a different type of nodule, or represent true phenocrystal cores crystallized at higher pressures than the rims. The orthopyroxene, found only in the nodules, is also moderately aluminous. In all respects it is within the range of common orthopyroxenes from spinel lherzolites.

The spinel analysis in Table $I$ is somewhat unusual. If the various spinel components are calculated in the order shown in the lower section of Table $\mathrm{I}$, the $\mathrm{Fe}^{+2}$ and $\mathrm{Fe}^{+3}$ ratio can be calculated. All Fe remaining after calculating all divalent cations to spinel components can be assigned to magnetite $\mathrm{Fe}^{+2} \mathrm{Fe}_{2}^{+3} \mathrm{O}_{4}$. Then $\mathrm{Fe}^{+2}$ and $\mathrm{Fe}^{+3}$ in all the calculated components can be summed separately. This procedure is essentially one discussed by Irvine (1965) with evidence that it is a valid method. The most striking feature is the large amount of $\mathrm{Fe}_{2} \mathrm{O}_{3}$ as comparied to $\mathrm{FeO}$. In most other analysis $\mathrm{FeO}$ exceeds $\mathrm{Fe}_{2} \mathrm{O}_{3}$. $\mathrm{Cr}_{2} \mathrm{O}_{3}$ is also rather high and naturally $\mathrm{Al}_{2} \mathrm{O}_{3}$ must then be low. At the same time $\mathrm{MgO}$ is relatively high.

Spinel is perhaps the most interesting mineral in spinel lherzolites since it alone seems to show such significant differences in composition from one occurrence to another ( $c f$. Bacon and Carmichael, 1973; Littlejohn and Greenwood, 1974). These differences must hold important clues to rather subtle regional variations in mantle composition or petrogenetic processes. Irvine (1964) laid the groundwork for study of chrome bearing spinels as petrogenetic indicators, which was extended to some degree by Jackson (1969). Although, we will not attempt a review here, further work on the basic phase relationships of spinels is becoming available. However, much more is required before it will be possible to make any quantitative use of these minerals as indicators, particularly at mantle temperatures and pressures. Irvine's work would indicate that our lherzolite spinels equilibrated at higher oxygen fugacities than most others. However, there may be a significant pressure effect at mantle depths. Irvine's (1965) $\Delta V$ value for his reaction $C$ is in error (Table III, p. 659).

Chemical Analysis Host Rock A portion of the host rock, carefully selected to avoid any nodule material, was analysed in the laboratory of the "Instituto de Geociências" of the University of São Paulo (Table II). A modified CIPW norm was then calculated from the analysis using a computer program (available from the first author). The analysis is quite typical of many basanite lavas in which lherzolites nodules are found. It is somewhat

Table II - Chemical and normative analysis of host rock

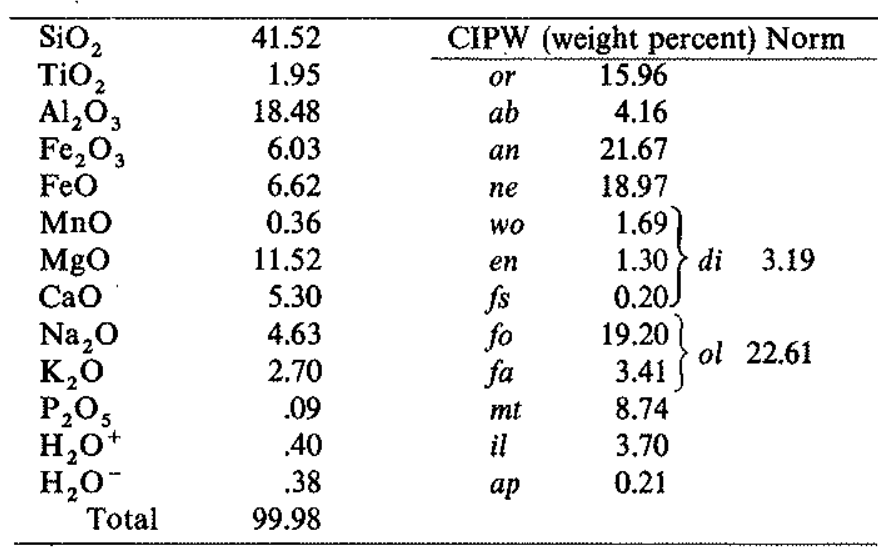

Analyst: Dr. Raphael Hypólito 
unusual in the rather high alumina and rather low calcium contents. Accumulation of phenocryst or nodule material could not produce these chemical anomalies; they must, therefore, be an intrinsic feature of the magma itself.

Strontium Isotopic Analyses Strontium isotopic analyses of the basanite host rock were made in the "Centro de Pesquisas Geocronológicas" of the University of São Paulo, using a double filament technique with a Varian model TH5 mass spectrometer. The $\mathrm{Sr}_{87} / \mathrm{Sr}_{86}$ ratio obtained was $0.7050 \pm 0.0015[1 \sigma]$ (normalized to $\mathrm{Sr}_{86} / \mathrm{Sr}_{88}=0.1194$ ).

Due to the very small amount of strontium, the analysis of the lherzolite nodules was carried out at the University of Texas in Dallas using a tripple filament technique and a mass spectrometer of $6^{\prime \prime}$ curvature and expanded scale system. The $\mathrm{Sr}_{87} / \mathrm{Sr}_{86}$ ratio of the lherzolite nodule (also normalized to $\mathrm{Sr}_{86} / \mathrm{Sr}_{88}=0.0094$ ) was determined to be $0.7050 \pm 0.0006$ [2 $\sigma$ ].

Statistically there is no significant difference between the ratios at a $3 \sigma$ level. The difference could, however; be real. Very slight contamination of the host basalt by crustal material could easily have produced the observed difference. A number of studies have also proven the existence of isotopic disequilibrium between nodules and host magma which could not be due to crustal contamination (Peterman et al., 1970; Paul, 1971). Both ratios fall within a range of values which is consistent with an origin in the mantle without a significant contribution of crustal material.

Potassium - Argon Age Dating The basanite was dated by K-Ar whole rock methods in the "Centro de Pesquisas Geocronológicas" of the University of São Paulo, using the technique described fully by Amaral et al. (1966). The results are presented in Table III. Although, not highly accurate the date coincides quite closely with one, previously published whole rock date for an "olivine basalt" from Asuncion (Comte and Hasui, 1971). Taken together, the dates indicate an Eocene age for the volcanism.

RESULTS AND DISCUSSION The orthopyroxene-clinopyroxene of Wood and Banno (1973) can be used to obtain an equilibrium temperature for lherzolite nodules. The analyses in Table I give a temperature of $1012^{\circ} \mathrm{C}$ by this technique. A temperature and pressure may also be obtained by using the method presented by O'Hara (1967a) based upon the distribution of calcium and aluminum between clinopyroxene and other phases in lherzolite assemblages. Computing the parameters $\alpha_{c}=50.7$ and $\beta_{c}=5.5$ from the analysis of clinopyroxene in Table $I$ and plotting them on O'Hara's Fig. 12.4 (1967a) gives a temperature of about $1100^{\circ}$ and a pressure near $15 \mathrm{~kb}$ (equivalent to depths near

Table III - Potassium argon dates

\begin{tabular}{llccccc}
\hline Sample N. * & & $\% \mathrm{~K}$ & $\begin{array}{c}\text { Ar }{ }^{40} \mathrm{rad} \\
10^{-5} \mathrm{cc} / \mathrm{gm} \mathrm{STP}\end{array}$ & $\%$ Atm. & $\begin{array}{c}\text { Date } \\
10^{6} \mathrm{yr}\end{array}$ \\
\hline SPK 2707 & Basanite & 1.438 & 0,210 & 97.6 & $36 \pm 11(2)$ \\
SPK 1407** & Olivine basalt & 1.043 & 0.195 & 82.0 & $46 \pm 7(2)$
\end{tabular}

Constants used in these determinations:

$$
\begin{aligned}
\text { total } & =0.530 \times 10^{-9} \mathrm{yr}^{-1} \\
\mathbf{K} & =0.586 \times 10^{-10} \mathrm{yr}^{-1} \\
\% \mathbf{K}_{40} \text { in } \mathrm{K} & =0.0119
\end{aligned}
$$

*Sample numbers refer to records of the "Centro de Pesquisas Geocronológicas"

**Sample number 16 of Comte and Hasui (1971) 
$45 \mathrm{~km}$ ). If we assume that the host magma equilibrated with the nodule, the variation of silica activity with pressure can also give an indication of the depth of possible equilibration (Nicholls et al., 1971). Assuming that the temperature of equilibration was not much higher (or lower) than the temperature of nepheline + feldspar crystallization in the groundmass after extrusion (i.e., rapid rise of the magma under approximately adiabatic conditions) a depth around $45 \mathrm{~km}$ is again indicated (Nicholls and Carmichael's, 1972, approach using the activity of alumina seems, however, to give temperatures and pressures which are too high).

Each of these methods requires some rather arbitrary assumptions. The general correspondence of the pressures and temperatures obtained $\sim 1100^{\circ} \mathrm{C} \sim 15 \mathrm{~kb}$ is, however, quite striking. This is also in accord with the temperatures and pressures obtained for spinel lherzolite nodules from basaltic rocks in other areas (O'Hara, 1967a, Fig. 12.6), and is well within the stability field of spinel peridotite as established by experiment (Wyllie, 1970). The temperature is below the beginning of melting in the dry peridotite system, but above the beginning of melting with even small amounts of water present (O'Hara, $1967 \mathrm{~b}$; Wyllie, 1971). The origin of the host magma however, cannot be unequivocably linked to the pressure and temperature of the nodules. The nodules may well be inclusions of material which is genetically unrelated to magmas which may have come from greater depths. The strontium isotopic results are consistent with a derivation of both the nodules and the host magma in the upper mantle. The slight difference in isotopic ratio may not be significant, and does not necessarily suggest that the nodules and magma were unrelated.

The potassium-argon age appears to confirm the close relationship of the volcanism in the Asuncion area with the development of the Ypacaray Graben. Similar basic alkaline volcanism is commonly associated with continental rifting and graben development (Beloussov, 1969).

Acknowledgements We would like to thank Dr. Martin Halpern of the University of Texas for determining the strontium isotopic ratio of the nodules. Collection of the samples and much of the analytical work was done while the first author was visiting in the "Instituto de Geociencias" of the University of São Paulo with the support of "Conselho Nacional de Pesquisas" (Proc. 7035/71). Further support for the first author was also provided by National Science Foundation (U.S.) Grant N. ${ }^{\circ} 40565$.

\section{REFERENCES}

ALBEE, A. L., and L. RAY - 1970 - Correction factors for electron probe microanalysis of silicates, oxides, carbonates, phosphates, and sulfates. Anal. Chem., 42: 1408-1 414

AMARAL, G., CORDANI, U. G., KAWASHITA, K., and REYNOLDS, J. H. - 1966 - Potassium Argon ages of basaltic rocks from southern Brazil: Geochim. Cosmochim. Acta, 30: 159m189

BACON, C. R., and GARMICHAEL, I, S. E. - 1973 - Stages in the P-T path of ascending basalt magma: an example from San Quintin, Baja Galifornia. Contr. Mineral. Petrol., 41: 1-22

BELOUSSOV, V. V. - 1969 - Continental Rifts. In Hart, P. J. ed. The Earths Crust and Upper Mantle. Amer. Geophys. Union, Geophys. Monography 13: 539-543

BROWN, F.H. $-1970-$ Zoning in some volcanic nephelines. Amer. Mineral., 55: 1670-1680

CARMICHAEL, I. S. E., TURNER, F. J., and VERHOOGEN, J. - 1974 - Igneous Petrology, Ist ed., New York, McGraw-Hill Book Co., 739 pp.

COMTE, D., and HASUI, Y. - 1971 - Geochronology of eastern Paraguay by the potassium-argon method. Rev. Bras. Geoc., 1: 33-43

FÚLFARO, V.J., and LANDIM, P.M.B. - 1971 - A Seqüéncia Godwânica Ocidental: Re* pública do Paraguai. An. XXV Congr. Bras. Geol., 2: 241-246, 
IRVINE, T. N. $-1965-$ Chromian spinel as a petrogenetic indicator: Part 1. Theory. Can. J. Earth Sci., 2: 648-672

JACKSON, E. D. - 1969 - Ghemical variation in coexisting chromite and olivine in the chromite zones of the Stillwater Complex in Symposium on Magmatic Ore Deposits, Econ. Geol. Monography 4: 41-71

LE BAS, M. J. - 1962 - The role of aluminum in igneous clinopyroxenes with relation to their parentage. Amer. J. Sci., 260: 267-288

LITTLEJOHN, A.L., and GREENWOOD, H.J. - 1974 - Lherzolite nodules in basalts from British Columbia, Canada. Can. J. Earth Sci., 11: 1 288n1 308

NICHOLLS, J., GARMICHAEL, I.S. E., and STORMER, J. C., Jr. - 1971 - Silica activity and $P$ (total) in igneous rocks. Contr. Mineral. Petrol., 33: 1-20

NICHOLLS, J., and GAR MICHAEL, I. S. E. - 1972 - The equilibration temperature and pressure of various lava types with spinel and garnetmperidotite. Amer. Mineral, 57: 941-959

O'HARA, M. J. - 1967a - Mineral parageneses in ultrabasic rocks in Wyllie, P. J. ed., Ultramafic and Related Rocks. John Wiley and Sons Inc., New York, 393-402

O'HARA, M. J. - 1967b - Mineral facies in ultramafic rocks in Wyllie, P.J. ed., Ultramafic and Related Racks. John Wiley and Sons, Inc., New York: 7-18

PAUL, D. K. -1971 - Strontium isotope studies on ultramafic inclusions from Dreiser Weiher, Germany. Contr. Mineral. Petrol., 34: 22-28

PETERMAN, Z. E., CARMICHAEL, I. S. E., and SMITH, A. L. -1970 - Strontium isotopes in quarternary basalts of southeastern California. Earth Planet. Sci. Letters, 7: 381-384.

STORMER, J.G., Jr. - 1972 - Mineralogy and petrology of the Raton-Clayton volcanic field, northeastern New Mexico, Geol. Soc. Amer. Bull., 83: $3299-3322$

STORMER, J. G., Jr. - 1973 - Calcium zoning in olivine and its relationship to silica activity and pressure. Geochim. Gosmochim. Acta, 37: 1815-1 821

STORMER, J. C., Jr., TORQUATO, J. R. F., and GOMES, C. B. - 1973 - Age and Compositions of Nephelinite and Enclosed Lherzolite Nodules from Asunción, Paraguay. II Congr. Latinoamericano Geol., Resumenes, pp. 186-187. Caracas, Venezuela

VERHOOGEN, J. - 1962 - Distribution of titanium between silicates and oxides in igneous rocks. Amer. J. Sci., 260: 211-220

WHITE, R., -1966 - Ultramafic inclusions in basaltic rocks from Hawaii. Contr. Mineral. Petrol., 12: 245-314

WOOD, B. J., and BANNO, S. - 1973 - Garnet-orthopyroxene and orthopyroxene - clinopyroxene relationships in simple and complex systems. Contr. Mineral. Petrol., 42: 109-124

WYLLIE, P. J. - 1970 - Ultramafic rocks and the upper mantle. Mineral. Soc. Amer., Spec. Pap. 3

WYLLIE, P. J. - 1971 - Role of water in magma generation and initiation of diapiric uprise in the mantle. Jour. Geophys. Res., 76: $1328-1338$ 